\title{
Dampak Penggunaan Media Sosial terhadap Gaya Hidup Hedonis Mahasiswa Universitas Tarumanagara
}

\author{
Indah Surya C, Rezi Erdiansyah \\ veronicaindah23@gmail.com,rezie@fikom.untar.ac.id
}

Fakultas Ilmu Komunikasi Universitas Tarumanagara

\begin{abstract}
This study discusses the impact of social media use of the hedonist lifestyle among university students of Tarumanagara. The purpose of this study is to know and understand about social media, the hedonist lifestyle, and how it influences the use of social media against hedonistic lifestyles. Population in this study is student and sorority University of Tarumanagara. The sample of this study used sampling technique with the Lemeshow formula with consideration and purpose at random without regard to the strata that exist in the population, students and sorority University of Tarumanagara. The data collection method in this study will use the questionnaire. Based on social media calculations positive and significant influence on hedonist lifestyle. The great influence of social media on hedonist lifestyle amounted to $88.8 \%$ while the remaining $11.2 \%$ was influenced by other variables not researched.
\end{abstract}

Keywords: hedonic, social media, students

\begin{abstract}
Abstrak
Penelitian ini membahas dampak penggunaan media sosial terhadap gaya hidup hedonis di kalangan mahasiswa Universitas Tarumanagara. Adapun tujuan penelitian ini adalah untuk mengetahui dan memahami media sosial, gaya hidup hedonis, dan bagaimana pengaruh penggunaan media sosial terhadap gaya hidup hedonis.Populasi dalam penelitian ini adalah mahasiswa dan mahasiswi Universitas Tarumanegara. Sampel penelitian ini menggunakan teknik sampling dengan rumus Lemeshow dengan pertimbangan dan tujuan secara acak tanpa memperhatikan strata yang ada dalam populasi, mahasiswa dan mahasiswi Universitas Tarumanegara. Metode pengumpulan data dalam penelitian ini akan menggunakan kuisioner. Berdasarkan perhitungan media sosial berpengaruh positif dan signifikan terhadap gaya hidup hedonis. Besar pengaruh media sosial terhadap gaya hidup hedonis sebesar $88,8 \%$ sementara sisanya $11,2 \%$ dipengaruhi oleh variabel-variabel lain yang tidak diteliti.
\end{abstract}

Kata Kunci: gaya hidup hedonis, mahasiswa, media sosial

\section{Pendahuluan}

Perkembangan teknologi yang semakin pesat dan canggih sudah tidak dapat dipungkiri. Perkembangan teknologi ini juga diikuti dengan pola gaya hidup di masyarakat. Manusia sebagai pengguna teknologi harus mampu memanfaatkan teknologi yang ada saat ini, maupun perkembangan teknologi yang selanjutnya dengan tepat. Salah satu manfaatnya adalah media untuk bersosialisasi antara satu dengan yang lainnya. Bersosialisasi pun dapat dilakukan menggunakan media sosial. Perkembangan penggunaan media sosial di Indonesia it uterus bertambah dengan pesat. Hal ini dapat dilihat berdasarkan laporan We Are Social menyebutkan pengguna internet di Indonesia pada tahun 2018 sebanyak 132.7 juta, tahun 2019 sebanyak 150 juta dan pada tahun 2020 disebutkan bahwa ada 175,4 juta. 
Media sosial mengajak siapa saja untuk berpartisipasi dengan memberi feedback secara terbuka, memberi komentar, serta membagi informasi dalam waktu yang cepat dan tak terbatas. Tidak dapat dipungkiri bahwa media sosial mempunyai pengaruh yang sangat besar dalam kehidupan seseorang. Seseorang yang awalnya kecil bisa menjadi besar dalam media sosisal atau sebaliknya. Bagi masyarakat khususnya kalangan mahasiswa, media sosial sudah menjadi candu yang membuat penggunanya tiada hari tanpa membuka media sosial.

Kalangan mahasiswa yang mempunyai media sosial biasanya memposting tentang kegiatan pribadinya, curhatan serta foto bersama teman temannya. Dalam media sosial siapapun dapat dengan bebas berkomentar serta menyalurkan pendapat tanpa rasa khawatir. Perilaku ini menyebabkan orang berlomba untuk membuat konten gaya hidup yang baru saat ini. Seperti yang dilansir oleh Suara.com pada Minggu, 31 Maret 2019. Seorang gadis terlilit banyak hutang akibat meniru gaya hidup mewah seperti selebgram. Selebgram sendiri biasanya adalah seseorang yang cukup terkenal dengan jumlah pengikut (follower) yang banyak di akun media sosial. Sebab itu banyak pengguna media sosial yang akhirnya mengikuti hal-hal yang dilakukan oleh selebgram panutannya dari berbagai aspek dan cara. Media sedikit banyak membawa pengaruh bagaimana khalayak melihat sebuah peristiwa, informasi maupun sebuah produk yang diterima senagai suati hal uang wajar adalah sosialisasi kebiasaan (Denis Mc. Quail, 2005).

Oleh karena itu, penulis ingin melihat adakah dampak dari penggunaan media sosial terhadap gaya hidup hedonis di kalangan mahasiswa Universitas Tarumanagara, yang sebagaimana merupakan tempat penulis mengemban pendidikan. Adapun penggunakan pengumpulan data yang dilakukan penulis menggunakan kuisoner yang disebarkan kepada mahasiswa Universitas Tarumanagara yang aktif berkuliah dari berbagai jurusan denagn teknik simple random sampling.

Sebelumnya, penulis ingin memberikan gambaran mengenai wajah komunikasi massa kontenpotrer. Saat ini komunikasi massa telah mengalami perubahan yang drastis. Selain publik tidak lagi mengalami ketergantungan terhadap media konvensional seperti TV, radio dansurat kabar cetak, menurut Alila Pramiyanti et al (2014) mengatakan bahwa media massa baru memungkinkan pengguna dapat berkomunikasi secara timbal balik atau komunikasi dua arah. Oleh karena itu, teknologi komunikasi semakin memperluas jangkauan kamonukasi massa, sebagaimana diungkapkan oleh Fatma Laili Khoirun Nida (2014) bahwa Beragam jenis media informasi yang dihasilkan telah menjadikan komunikasi massa memiliki eksistensi yang kuat dalam pola komunikasi masyarakat yang modern.

Namun, new media telah melahirkan media sosial yang menggunakan teknologi komunikasi mutakhir berbasis web. Nisa Khairuni (2016) mengatakan perkembangan media sosial semakin hari semakin cepat, beragam, unik, merambah beragam segmen dan berkarakteristik, dengan demikian media sosial telah menjadi suatu media massa baru. Alila Pramiyanti, Idola Perdini Putri, Reni Nureni (2014) saat ini media sosial merupakan media komunikasi yang efektif, tranparan dan efisien serta memiliki peran penting sebagai agen perubahan dan pembaharuan.

Secara umum Gaya hidup mengandung pengertian sebagai cara bagaimana seseorang mengonsumsi waktu dan uangnya untuk mengaktualisasikan dirinya. Gaya hidup juga dapat menjadi ajang ekspresi dan adaptasi seseorang terhadap budaya yang tengah melanda, sehingga tindakannya didasarkan pada pola baru yang dilahirkan akibat perkembangan zaman. Dalam hal ini, bentuk budaya modern menghadirkan gaya hidup modern, yang menjadi acuan dalam bersikap maupun bertindak ( Monanda 
Rizka, 2017). Selanjutnya Setiadi (2010) menyebutkan bahwa gaya hidup adalah cara hidup seseorang dalam menghabiskan waktu, ketertarikan mereka, dan apa yang dipikirkan tentang dirinya dan lingkungannya. Sejalan dengen pengertian tersebut, Anggraini dan Fauzan (2017) mengemukakan bahwa gaya hidup mempengaruhi kebutuhan, keinginan dan perilakunya.

Berdasarkan hasil penelitian terdahulu terlihat bahwa gaya hidup hedonis dipengaruhi oleh banyak faktor. Nazir (2015) menemukan bahwa pemahaman para remaja pada uang meliputi pemahaman mengani pentingnya uang, keterlibatan pribadi dengan uang, banyaknya waktu yang dihabiskan untuk memikirkan masalah keuangan, dan keterampilan memaknai uang berakibat pada gaya hidup hedonis para remaja. Selanjutnya Nadia Franciska Sukarno dan Endang Sri Indrawati (2018) menyebutkan konformitas teman sebaya meliputi upaya para remaja untuk menjaga harmonisasi dan dukungan emosi dari lingkungan teman- temannya pada suatu kelompok mendorong para remaja melakukan gaya hidup hedonis sebagai bentuk penyesuaian diri. Rizki Monanda (2017) membuktikan bahwa penggunaan media sosial dalam hal ini Instagram berpengaruh terhadap gaya hidup para remaja.

\section{Metode Penelitian}

Penelitian yang menggunakan pendekatan yang tepat dapat menggambarkan masalah yang ingin dihadapi serta dapat mengatasinya. Hal itu mendasari peneliti untuk menggunakan pendekatan kuantitatif deskriptif. Pendekatan kuantitatif deskriptif ini berlandaskan pada filsafat positivisme, digunakan untuk meneliti pada populasi atau sampel tertentu, pengumpulan data menggunakan instrumen penelitian, analisis data bersifat kuantitatif/statistik, dengan tujuan untuk menguji hipotesis yang telah ditetapkan (Sugiyono,2012).

Teknik yang digunakan dalam metode ini peniliti menggunakan teknik simple random sampling, yakni teknik yang paling sederhana (simple). Sampel diambil secara acak, tanpa memperhatikan usia, jenis kelamin, status sosial,dsb. Menurut Sugiyono (2001), teknik simple random sampling adalah teknik pengambilan sampel dari anggota populasi yang dilakukan secara acak tanpa memperhatikan strata yang ada dalam populasi itu.

\section{Hasil Temuan dan Diskusi}

Berdasarkan dari hasil penyebaran kuisoner, responden dari penelitian ini dapat dideskripsikan sebagai berikut :

a. Jenis kelamin diketahui bahwa jumlah responden perempuan lebih banyak dibandingkan perempuan, yaitu 65 orang perempuan $(65 \%)$ dan 35 orang laki-laki (35\%)

b. Asal fakultas diketahui bahwa sebagian besar asal fakultas responden berasal Ilmu Komunikasi yaitu sebanyak 47 atau $47 \%$ responden dan sebagian kecil responden berasal dari Teknik yaitu sebanyak 6 atau $6 \%$ responden. Berdasarkan angkatan kuliah diketahui bahwa sebagian besar angkatan responden berada pada angkatan 2017 yaitu sebanyak 39 atau 39\% responden dan sebagian kecil berada pada angkatan 2018 yaitu sebanyak 15 atau 15\% responden.

c. Jenis media sosial yang digunakan diketahui bahwa jumlah media sosial yang digunakan responden lebih dari satu jenis media soosial dan yang terbanyak 
Indah Surya C, Rezi Erdiansyah: Dampak Penggunaan Media Sosial terhadap Gaya Hidup Hedonis Mahasiswa Universitas Tarumanagara

adalah Youtube, Whatsapp, Instagram, yaitu 39 atau 39\% responden.

Berdasarkan online shop yang diikuti diketahui bahwa sebagian besar mengikuti lebih dari 5 online shop yaitu sebanyak 42 atau $42 \%$ responden dan sebagian kecil mengikuti 4-5 online shop yaitu sebanyak 10 atau $10 \%$ responden.

\section{Variabel Media Sosial}

Tabel 1. Uji Reliabilitas Variabel Media Sosial

\begin{tabular}{|c|c|c|c|c|}
\hline \multicolumn{5}{|c|}{ Item-Total Statistics } \\
\hline & $\begin{array}{l}\text { Scale Mean if } \\
\text { Item Deleted }\end{array}$ & $\begin{array}{l}\text { Scale Variance } \\
\text { if Item Deleted }\end{array}$ & $\begin{array}{l}\text { Corrected } \\
\text { Item-Total } \\
\text { Correlation }\end{array}$ & $\begin{array}{c}\text { Cronbach's } \\
\text { Alpha if Item } \\
\text { Deleted }\end{array}$ \\
\hline MS1 & 15.47 & 13.039 & .400 & .786 \\
\hline MS2 & 16.46 & 10.231 & .631 & .741 \\
\hline MS3 & 16.94 & 10.057 & .694 & .727 \\
\hline MS4 & 16.48 & 10.454 & .639 & .740 \\
\hline MS5 & 16.54 & 11.463 & .482 & .771 \\
\hline MS6 & 16.67 & 11.173 & .423 & .787 \\
\hline MS7 & 16.22 & 12.355 & .387 & .786 \\
\hline
\end{tabular}

Sumber: Pengolahan Data Pribadi

Berdasarkan hasil perhitungan, dapat disimpulkan bahwa tujuh butir pernyataan variabel Media Sosial memiliki nilai Corrected Item-Total Correlation $>0,200$ yang berarti telah valid.

2. Variabel Gaya Hidup Hedonis

Tabel 2. Uji Reliabilitas Variabel Gaya Hidup Hedonis

\begin{tabular}{lr|r|r|r} 
& $\begin{array}{c}\text { Scale Mean if } \\
\text { Item Deleted }\end{array}$ & $\begin{array}{c}\text { Scale Variance } \\
\text { if Item Deleted }\end{array}$ & $\begin{array}{c}\text { Corrected } \\
\text { Item-Total } \\
\text { Correlation }\end{array}$ & $\begin{array}{c}\text { Cronbach's } \\
\text { Alpha if Item } \\
\text { Deleted }\end{array}$ \\
\hline GHH1 & 26.58 & 41.600 & .560 & .880 \\
\hline GHH2 & 27.05 & 39.705 & .717 & .872 \\
\hline GHH3 & 27.06 & 39.976 & .737 & .871 \\
\hline GHH4 & 27.16 & 42.116 & .516 & .882 \\
\hline GHH5 & 26.43 & 43.076 & .324 & .893 \\
\hline GHH6 & 26.91 & 40.325 & .666 & .874 \\
\hline GHH7 & 26.19 & 42.095 & .435 & .886 \\
\hline GHH8 & 26.62 & 40.783 & .606 & .877 \\
\hline GHH9 & 27.28 & 39.800 & .727 & .871 \\
\hline GHH10 & 26.80 & 40.384 & .541 & .881 \\
\hline GHH11 & 26.02 & 43.070 & .451 & .884 \\
\hline GHH12 & 27.07 & 40.530 & .644 & .875 \\
\hline GHH13 & 26.71 & 40.188 & .629 & .876 \\
\hline S & & & &
\end{tabular}

Sumber: Pengolahan Data Pribadi

Berdasarkan hasil perhitungan, dapat disimpulkan bahwa tiga belas (13) butir pernyataan variabel Gaya Hidup Hedonis memiliki nilai Corrected Item-Total Correlation $>0,200$ yang berarti telah valid 


\section{Uji Reliabilitas}

1. Variabel Media Sosial

Tabel 3. Hasil Uji Reliabilitas Variabel Media Sosial

\begin{tabular}{|c|c|}
\hline \multicolumn{2}{|c|}{ Reliability Statistics } \\
\hline $\begin{array}{c}\text { Cronbach's } \\
\text { Alpha }\end{array}$ & $\mathrm{N}$ of Items \\
\hline .79 & 7 \\
\hline
\end{tabular}

Sumber: Pengolahan Data Pribadi

Dari pengujian reliabilitas dengan menggunakan program SPSS 25 terhadap 7 butir variabel media sosial, didapat nilai Cronbach's Alpha sebesar 0.791 yang berarti alat ukur butir-butir media sosial tersebut reliabel karena nilai Cronbach's Alpha > 0,7.

2. Variabel Gaya Hidup Hedonis

Tabel 4. Hasil Uji Reliabilitas Variabel Gaya Hidup Hedonis

\begin{tabular}{|c|c|}
\hline \multicolumn{2}{|c|}{ Reliability Statistics } \\
\hline $\begin{array}{c}\text { Cronbach's } \\
\text { Alpha }\end{array}$ & $\mathrm{N}$ of Items \\
\hline .88 & 13 \\
\hline
\end{tabular}

Sumber: Pengolahan Data Pribadi

Dari pengujian reliabilitas dengan menggunakan program SPSS 25 terhadap 13 butir variabel gaya hidup hedonis, didapat nilai Cronbach's Alpha sebesar 0.887 yang berarti alat ukur butir-butir gaya hidup hedonis tersebut reliabel karena nilai Cronbach's Alpha $>0,7$.

\section{Uji Normalitas}

Tabel 5. Uji Normalitas

\begin{tabular}{|c|c|c|c|}
\hline \multicolumn{4}{|c|}{ One-Sample Kolmogorov-Smirnov Test } \\
\hline & & Media Sosial & $\begin{array}{l}\text { Gaya Hidup } \\
\text { Hedonis }\end{array}$ \\
\hline $\mathrm{N}$ & & 100 & 100 \\
\hline \multirow[t]{2}{*}{ Normal Parameters ${ }^{\mathrm{a}, \mathrm{b}}$} & Mean & 2.7329 & 2.2300 \\
\hline & Std. Deviation & .54960 & .53142 \\
\hline \multirow[t]{3}{*}{ Most Extreme Differences } & Absolute & .084 & .064 \\
\hline & Positive & .073 & .064 \\
\hline & Negative & -.084 & -.043 \\
\hline Test Statistic & & .084 & .064 \\
\hline Asymp. Sig. (2-tailed) & & $.075^{\mathrm{c}}$ & $.200^{\mathrm{cd}}$ \\
\hline \multicolumn{4}{|c|}{$\begin{array}{l}\text { a. Test distribution is Normal. } \\
\text { b. Calculated from data. } \\
\text { c. Lilliefors Significance Correction. } \\
\text { d. This is a lower bound of the true significance. } \\
\text { Sumber: Pengolahan Data Pribadi }\end{array}$} \\
\hline
\end{tabular}


Berdasarkan hasil pengolahan data dari uji normalitas, didapatkan nilai sig (p) Kolmogorov Smirnov sebesar $0.075>0,05$ untuk variabel media sosial, dan $0.200>$ 0,05 untuk variabel gaya hidup hedonis, sehingga dapat disimpulkan bahwa distribusi data variabel media sosial dan gaya hidup hedonis adalah normal.

\section{Uji Hipotesis}

Tujuan dari pengujian hipotesis adalah untuk mengetahui apakah hipotesis $\mathrm{H} 0$ yang diuji diterima atau ditolak. Hal ini dapat dilihat dengan melihat nilai signifikansi (p) dari masing- masing hasil uji hipotesis. Adapaun batas toleransi kesalahan ( ) penerimaan dan penolakan hipotesis adalah 5\%. Apabila $\mathrm{p}<$ atau $<0,05$ maka terdapat pengaruh yang signifikan variabel $\mathrm{x}$ terhadap variabel $\mathrm{y}$.

1. Koefisien Korelasi

Tabel 6. Koefisien Korelasi

\begin{tabular}{|c|c|c|c|c|}
\hline \multicolumn{5}{|c|}{ Model Summary } \\
\hline Model & $\mathrm{R}$ & R Square & $\begin{array}{l}\text { Adjusted R } \\
\text { Square }\end{array}$ & $\begin{array}{l}\text { Std. Error of } \\
\text { the Estimate }\end{array}$ \\
\hline 1 & $.715^{\mathrm{a}}$ & .511 & .506 & 37368 \\
\hline
\end{tabular}

Dari hasil perhitungan diketahui nilai koefisien determinasi pada tabel $\mathrm{R}$ square sebesar 0.888 menunjukkan bahwa $88.8 \%$ gaya hidup hedonis dipengaruhi oleh media sosial, sementara sisanya $11,2 \%$ dipengaruhi oleh variabel-variabel lain.

2. Uji Hipotesis (Uji T)

Tabel 6. Koefisien Korelasi

\begin{tabular}{|c|c|c|c|c|c|c|}
\hline \multirow{3}{*}{\multicolumn{2}{|c|}{ Model }} & \multicolumn{3}{|c|}{ Coefficients ${ }^{\mathrm{a}}$} & \multirow[b]{3}{*}{$\mathrm{T}$} & \multirow[b]{3}{*}{ Sig. } \\
\hline & & \multicolumn{2}{|c|}{$\begin{array}{l}\text { Unstandardized } \\
\text { Coefficients }\end{array}$} & \multirow{2}{*}{$\begin{array}{c}\text { Standardized } \\
\text { Coefficients } \\
\text { Beta }\end{array}$} & & \\
\hline & & B & Std. Error & & & \\
\hline 1 & (Constant) & .342 & .190 & & 1.795 & .076 \\
\hline & Media Sosial & .691 & .068 & .715 & 10.111 & .000 \\
\hline
\end{tabular}

a. Dependent Variable: Gaya Hidup Hedonis

Sumber: Pengolahan Data Pribadi

Persamaan regresi: Gaya hidup hedonis $=0.342+0.691$ Media Sosial

\section{Hipotesis}

Berdasarkan hasil analisis data diketahui bahwa nilai $\mathrm{t}=10.111$ dan tingkat signifikansi $=0.000<0,05$. Karena nilai $\mathrm{p}<0,05$ maka $\mathrm{H} 0$ ditolak dan $\mathrm{H} 1$ diterima, yang berarti terdapat pengaruh positif signifikan media sosial terhadap gaya hidup hedonis. Dengan demikian semakin tinggi penggunaan media sosial maka semakin tinggi gaya hidup hedonis, sebaliknya semakin rendah media sosial maka semakin rendah gaya hidup hedonis. 


\section{Simpulan}

Hasil penelitian menunjukkan bahwa Media Sosial berpengaruh positif dan signifikan terhadap gaya hidup hedonis. Besar pengaruh media sosial terhadap gaya hidup hedonis sebesar $88,8 \%$ sementara sisanya $11,2 \%$ dipengaruhi oleh variabelvariabel lain yang tidak diteliti. Hal ini menggambarkan bahwa semakin sering menggunakan media sosial, kerap memberikan respon terhadap postingan barang atau produk bermerek yang disukai, dan mengikuti perkembangan mode dari akun media sosial yang diikuti, maka semakin responden merasa lebih sering menghabiskan waktu luang dikeramaian bersama teman daripada dirumah/kost, sering menghabiskan uang untuk nongkrong dengan teman daripada membeli buku dan alat tulis, sering berbelanja barang atau produk yang diinginkan, dan berbelanja suatu produk karena sering melihatnyna tren di media sosial.

\section{Ucapan Terima Kasih}

Peneliti ingin mengucapkan banyak terima kasih kepada seluruh narasumber penulis yang telah memberikan informasi terkait dengan penelitian yang penulis lakukan.

\section{Daftar Pustaka}

Khairuni, Nisa. Dampak Positif Dan Negatif Sosial Media Terhadap Pendidikan Akhlak Anak (Studi Kasus Di Smp Negeri 2 Kelas Viii Banda Aceh). Jurnal Edukasi Volume 2 Nomor 1 Tahun 2016. ISSN : 2460-4917. E-ISSN : 24605794.

Monanda, Rizka. (2017). Pengaruh Media Sosial Instagram@Awkarin Terhadap Gaya Hidup Hedonis Di Kalangan Followers Remaja. JOM FISIP Vol. 4 No. 2 - Oktober 2017.

Putri, Wilga Secsio Ratsja , R. Nunung Nurwati, \& Meilanny Budiarti S. (2016). Pengaruh Media Sosial Terhadap Perilaku Remaja. PROSIDING KS: RISET \& PKM Volume: 3, Nomor: 1 Hal: 1 - 154. ISSN: 2442-4480.

Stanley Lemeshow, David W. Hosmer J, Janeile Klas \& Stephen K. Lwanga, 1997, Besar Sampel dalam Penelitian Kesehatan, Gajah Mada University Press, Yogyakarta.

We Are Social. (2019). Digital In 2019. Maret 15,2020. < https://wearesocial.com/global-digital-report-2019 >, diunduh tanggal 15 Maret 2020.

We Are Social. (2020). Digital In 2020. Maret 15,2020. < https://wearesocial.com/digital-2020 >, diunduh tanggal 15 Maret 2020. 